\title{
Potential mechanisms linking probiotics to diabetes: a narrative review of the literature
}

\author{
Mecanismos potenciais ligando probióticos a diabetes: uma revisão \\ narrativa da literatura
}

\author{
Maryam Miraghajani', Somayeh Shahraki Dehsoukhteh", Nahid Rafie"', Sahar Golpour Hamedani"', Sima Sabihi"', Reza Ghiasvand"v \\ Isfahan University of Medical Sciences, Isfahan, Iran
}

IPhD. Doctoral Student, Cancer Research Center, Shahid Beheshti University of Medical Sciences, Tehran, Iran.

"MSc. Coach, Department of Statistics, Faculty of Sciences, Zabol University, Zabol, Iran.

"'MSc. Master's Student, Food Security Research Center, Department of Community Nutrition, School of Nutrition and Food Science, Isfahan University of Medical Sciences, Isfahan, Iran. IvPhD. Professor, Food Security Research Center, Department of Community Nutrition, School of Nutrition and Food Science, Isfahan University of Medical Sciences, Isfahan, Iran.

\section{KEY WORDS:}

Molecular mechanisms of pharmacological action. Probiotics.

Diabetes mellitus.

Review.

Microbiota.

\section{PALAVRAS-CHAVE:}

Mecanismos moleculares de ação farmacológica. Probióticos.

Diabetes mellitus.

Revisão.

Microbiota.

\begin{abstract}
CONTEXT AND OBJECTIVE: Some studies have suggested a wide range of possible mechanisms through which probiotics may play a role in diabetes prevention and treatment. However, the underlying mechanisms are not fully understood. We conducted this study to review the potential mechanisms suggested for the effect of probiotics in diabetes.

DESIGN AND SETTING: Narrative review conducted at the Food Security Research Center of Isfahan. METHODS: A search in the electronic databases MEDLINE (PubMed), Cochrane Library, Web of Science and Google scholar was performed up to October 2016.

RESULTS: The initial search yielded 1214 reports. After removing duplicates, 704 titles and abstracts were screened. Finally, out of 83 full-text articles that were reviewed for eligibility, 30 articles were included in the final analysis. The anti-diabetic mechanisms for probiotics reported encompass intraluminal and direct effects on the intestinal mucosa and microbiota $(n=13)$, anti-inflammatory and immunomodulatory effects ( $n=10)$, antioxidative effects $(n=5)$, effects on endoplasmic reticulum (ER) stress and expression of genes involved in glucose homeostasis and insulin resistance $(n=6)$, with some studies pointing to more than one mechanism.

CONCLUSION: The results may throw some light on the capacity of probiotics as a novel approach towards controlling diabetes. However, further human studies are warranted to elucidate and confirm the potential role of probiotics in diabetes prevention and treatment. Also, it needs to be ascertained whether the effectiveness of probiotics in diabetes prevention and treatment is dependent on the strain of the microorganisms.
\end{abstract}

\section{RESUMO}

CONTEXTO E OBJETIVO: Alguns estudos têm sugerido ampla gama de possíveis mecanismos, pelos quais os probióticos podem desempenhar um papel na prevenção e tratamento do diabetes. No entanto, os mecanismos subjacentes não são totalmente compreendidos. Realizamos este estudo para revisar os possíveis mecanismos sugeridos para o efeito dos probióticos na diabetes.

TIPO DE ESTUDO E LOCAL: Revisão narrativa conduzida no Food Security Research Centro de Isfahan. MÉTODOS: Busca sistemática nas bases de dados eletrônicas MEDLINE (PubMed), Cochrane Library, Web of Science e Google scholar até outubro de 2016.

RESULTADOS: A busca inicial resultou em 1.214 artigos. Após a remoção de duplicatas, foram pesquisados 704 títulos e resumos. Finalmente, de 83 artigos completos revisados para elegibilidade, 30 foram incluídos na análise final. Os mecanismos antidiabéticos relatados dos probióticos abrangem efeitos intraluminais e diretos na mucosa e microbiota intestinal $(n=13)$, efeitos anti-inflamatórios e imunomoduladores $(n=$ 10), efeitos antioxidativos ( $n=5)$, efeitos sobre o estresse de retículo endoplasmático (RE) e expressão de genes envolvidos na homeostase da glicose e resistência à insulina $(n=6)$, com alguns estudos apontando para mais de um mecanismo.

CONCLUSÃO: Os resultados podem lançar alguma luz sobre os probióticos como uma nova abordagem no controle do diabetes, no entanto, mais estudos em humanos são justificados para elucidar e confirmar o papel potencial dos probióticos na prevenção e tratamento do diabetes. Além disso, deverá ser determinado se a eficácia dos probióticos na prevenção e tratamento do diabetes é dependente da cepa dos microrganismos. 


\section{INTRODUCTION}

Probiotics are live microorganisms that may exert beneficial effects regarding the sufficiency of consumption via their impact on the microbial balance of the gut. ${ }^{1}$ The most commonly used probiotics are Lactobacillus, Bifidobacterium and Saccharomyces boulardii, which have different effects depending on the dosage, length of therapy and administration route. ${ }^{2}$

Given the influence of the gut microbiota on metabolic conditions including diabetes and on improving host metabolism, the concept of manipulating the gut microbiota has gained considerable interest over recent years. Use of probiotics has been suggested as one of the approaches towards modifying the clonal flora. ${ }^{3}$

Diabetes mellitus is a chronic metabolic disease with major complications largely influenced by glycemic measures. ${ }^{1}$ The Global Burden of Disease 2015 study (GBD 2015) showed that diabetes was among the leading causes of years of life lost (YLLs) in most regions. ${ }^{2}$ Also, diabetes was shown to be a leading cause of disability-adjusted life years (DALYs), for which the observed burden exceeded expected levels in many localities. ${ }^{3}$ The rise in diabetes prevalence is set to pose one of the most important challenges to healthcare systems over the coming years. ${ }^{4}$

A growing body of evidence suggests that favorable associations exist between probiotic consumption and metabolic profile among diabetes subjects. ${ }^{5}$ However, the potential mechanisms underlying the effects of probiotics on glycemia-related parameters are not fully understood. One of the main mechanisms postulated may involve increased glucagon-like peptide 1 (GLP-1) secretion from enteroendocrine L-cells to improve carbohydrate metabolism, decrease glucotoxicity and increase insulin sensitivity of target cells. ${ }^{6}$ Other proposed mechanisms to explain the action of probiotics on diabetes relate to anti-inflammatory, antioxidant and immunomodulatory effects and alteration of the expression of some genes involved in diabetes. ${ }^{7-10}$

Moreover, probiotic intake affects the structure of the gut flora, which might improve the integrity of the intestinal epithelium, weaken the immune responses and diminish the toll-like receptor 4 pathway, which in turn reduces pro-inflammatory signaling and enhances insulin sensitivity. ${ }^{11,12}$

Given the various statements regarding the effects of probiotics on diabetes that have been made, the aim of the present study was to focus on possible mechanisms for probiotics that might explain some of their beneficial effects in relation to diabetes, in the form of a review.

\section{OBJECTIVE}

The aim of the present study was to focus on possible mechanisms for probiotics that might explain some of their beneficial effects in relation to diabetes, in the form of a narrative review.

\section{METHODS}

\section{Search strategy}

A search of the electronic databases MEDLINE (via PubMed) and Cochrane Library (via Wiley) and the electronic repositories Web of Science and Google Scholar was performed. The search was last performed in October 2016, using combinations of search terms including "probiotics" OR "probiotic" OR "lactic acid bacteria" OR "lactobacillus" OR "lactobacilli" OR "bifidobacterium" OR "bifidobacteria” AND “diabetes mellitus", without any restrictions, in order to find studies focusing on the mechanisms linking probiotics with diabetes.

\section{Eligibility criteria}

Studies were included if they assessed the effect of a single or combination of live probiotics on diabetes. On the other hand, studies presented only as abstracts with no full-text available, non-English literature, studies involving patients with other metabolic diseases such as obesity or hypercholesterolemia, studies with no probiotic genus/strains reported, studies using synbiotics (i.e. probiotics combined with prebiotics), study protocols, pilot studies, letters, editorials, obviously irrelevant studies and studies that included non-diabetic patients or animals were all excluded.

\section{Selection strategy}

The eligibility of all potential studies identified for inclusion was independently assessed by two reviewers. Discrepancies regarding study inclusion were resolved through discussion with a third reviewer. Initially, titles and abstracts were verified and then an assessment of full texts was conducted. The reference lists of eligible articles or relevant review papers were screened for other eligible papers.

\section{Data extraction}

Study characteristics from eligible articles such as the first author's name, year of publication, study design, subjects or animal models, probiotic strain and suggested mechanisms for probiotics on diabetes were extracted by two authors. The details of all eligible articles are outlined in Table 1. ${ }^{10-39}$

\section{RESULTS}

Our initial search retrieved 1,214 articles. After removing duplicates, 704 titles and abstracts were screened. Then, from among these articles, 83 full texts were assessed for eligibility. Finally, 30 studies were included in this review. A flowchart of the study selection process is illustrated in Figure 1.

\section{Local effects of probiotics in the intestine}

Endotoxemia (increased circulatory levels of bacterial lipopolysaccharides) has been identified as a triggering factor for insulin 
Table 1. Characteristics of the studies included

\begin{tabular}{|c|c|c|c|}
\hline Study & $\begin{array}{c}\text { Study design, animals } \\
\text { or participants }\end{array}$ & Probiotic strain & Mechanisms suggested \\
\hline $\begin{array}{l}\text { Balakumar } \\
\text { et al. }{ }^{10}\end{array}$ & $\begin{array}{l}\text { Experimental study. } \\
\text { Diabetic mice fed on } \\
\quad \text { high-fat diet }\end{array}$ & $\begin{array}{l}\text { Lactobacillus plantarum } \\
\text { MTCC5690 and Lactobacillus } \\
\text { fermentum MTCC5689 }\end{array}$ & $\begin{array}{l}\text { - preventing the translocation of bacterial lipopolysaccharides (LPS) into the } \\
\text { systemic circulation } \\
\text { - increasing the level of GLP-1 ameliorating ER stress }\end{array}$ \\
\hline $\begin{array}{l}\text { Dolpady } \\
\text { et al. }{ }^{13}\end{array}$ & $\begin{array}{l}\text { Experimental study. } \\
\text { NOD mice }\end{array}$ & $\begin{array}{c}\text { Lactobacillaceae-enriched } \\
\text { probiotic VSL\#3 }\end{array}$ & $\begin{array}{l}\text { - enriching the local microbiota with Lactobacillaceae strains, increasing Clostridia } \\
\text { and Rikenellaceae species and reducing the Bacteroidetes strain S24-7 } \\
\text { producing immunological tolerance in intestinal microenvironment with low } \\
\text { expression of inflammatory IL-1 } \beta \text {; promoting CD103+ DC differentiation and } \\
\text { reducing the Teff/Treg cell ratios within the gut mucosa, mesenteric lymph } \\
\text { nodes (MLN) and peripheral lymph nodes (PLN) }\end{array}$ \\
\hline $\begin{array}{l}\text { Hung } \\
\text { et al. }{ }^{11}\end{array}$ & $\begin{array}{l}\text { Experimental study. } \\
\text { Sprague-Dawley rats } \\
\text { with IGT }\end{array}$ & $\begin{array}{c}\text { Lactobacillus paracasei } \\
\text { subsp. paracasei NTU } 101\end{array}$ & $\begin{array}{l}\text { - increasing Bifidobacterium spp. and improvement of intestinal environment } \\
\text { - preserving gut integrity and preventing translocation of bacterial LPSs into } \\
\text { systemic circulation }\end{array}$ \\
\hline Tian et al. ${ }^{12}$ & $\begin{array}{l}\text { Experimental study. } \\
\text { High fat diet and } \\
\text { streptozotocin-induced } \\
\text { type } 2 \text { diabetic rats }\end{array}$ & $\begin{array}{l}\text { Lactobacillus paracasei } \\
\text { subsp. paracasei G15 and } \\
\text { Lactobacillus casei Q14 }\end{array}$ & $\begin{array}{l}\text { - reducing the intestinal mucosal permeability and improving the epithelial } \\
\text { barrier function through modification of the gut microbiota and preventing } \\
\text { translocation of bacterial lipopolysaccharides into systemic circulation }\end{array}$ \\
\hline $\begin{array}{l}\text { Duan } \\
\text { et al. }{ }^{14}\end{array}$ & $\begin{array}{l}\text { Experimental study. } \\
\text { Diabetic rats }\end{array}$ & $\begin{array}{l}\text { Human lactobacilli } \\
\text { engineered to secrete GLP- } \\
1(1-37)\end{array}$ & - reprograming intestinal cells into glucose-responsive in \\
\hline $\begin{array}{l}\text { Holowacz } \\
\text { et al. }{ }^{15}\end{array}$ & $\begin{array}{l}\text { Experimental study. } \\
\text { High-fat-diet } \\
\text { C57/BL6J mice }\end{array}$ & $\begin{array}{l}\text { Multispecies Lactobacillus- } \\
\text { and Bifidobacterium- } \\
\text { containing probiotic } \\
\text { mixture }\end{array}$ & $\begin{array}{l}\text { - } \text { reducing expression of the gene encoding } \mathrm{CCL}-2 \\
\text { - } \text { preventing macrophage infiltration of adipose tissue and insulin resistance }\end{array}$ \\
\hline Le et al. ${ }^{16}$ & $\begin{array}{l}\text { Experimental study. } \\
\text { C57BL/6J mice with } \\
\text { streptozotocin (STZ)- } \\
\text { induced diabetes }\end{array}$ & $\begin{array}{l}\text { Bifidobacterium species } \\
\text { (spp.) }\end{array}$ & $\begin{array}{l}\text { - increasing the levels of proteins related to innate immune responses } \\
\text { - reducing transcription of target genes such as those of pro- inflammatory cytokines } \\
\text { - inducing differentiation of adipocytes into a cell type capable of inducing } \\
\text { insulin sensitivity in diabetic mice }\end{array}$ \\
\hline Park et al. ${ }^{17}$ & $\begin{array}{l}\text { Experimental study. } \\
\text { C57BL/KsJ-db/db } \\
\text { (db/db) mice }\end{array}$ & Lactobacillus rhamnosus GG & $\begin{array}{l}\text { - } \text { reducing infiltration and activation of macrophage in white adipose tissues } \\
\text { - decreasing the expression of ER stress genes in skeletal muscle and alleviating } \\
\text { endoplasmic reticulum (ER) stress and lipotoxicity }\end{array}$ \\
\hline $\begin{array}{l}\text { Stenman } \\
\text { et al. }{ }^{18}\end{array}$ & $\begin{array}{l}\text { Experimental study. } \\
\text { Male }(57 \mathrm{BI} / 6 \mathrm{~J} \text { mice }\end{array}$ & $\begin{array}{l}\text { Bifidobacterium animalis ssp. } \\
\text { lactis } 420 \text { (B420) }\end{array}$ & $\begin{array}{l}\text { - increasing the ileum GLP-1 concentration and increasing the amount of } \\
\text { insulin released from pancreatic beta cells }\end{array}$ \\
\hline Wei et al. ${ }^{19}$ & $\begin{array}{l}\text { Experimental study. } \\
\text { Streptozotocin-induced } \\
\text { type } 1 \text { diabetic mice }\end{array}$ & $\begin{array}{l}\text { Lactobacillus kefiranofaciens } \\
\text { M and Lactobacillus kefiri } \mathrm{K}\end{array}$ & $\begin{array}{l}\text { - stimulating the production of GLP-1 } \\
\text { - modulating the gut microbiota by increasing the number of Gram-positive } \\
\text { and decreasing the number of Gram-negative bacteria } \\
\text { - inhibiting the pro-inflammatory and inflammatory cytokines, and elevating } \\
\text { the production of IL-10 }\end{array}$ \\
\hline $\begin{array}{l}\text { Everard } \\
\text { et al. }{ }^{20}\end{array}$ & $\begin{array}{l}\text { Experimental study. Type } \\
2 \text { diabetic } \mathrm{db} / \mathrm{db} \text { mice }\end{array}$ & Saccharomyces boulardii & - changing the gut microbiota composition \\
\hline Kim et al. ${ }^{21}$ & $\begin{array}{l}\text { Experimental study. } \\
\text { Rat L6 skeletal muscle } \\
\text { cells and KK-AY mouse } \\
\text { NIDDM model }\end{array}$ & $\begin{array}{l}\text { Bifidobacterium lactis } \\
\text { HY8101 }\end{array}$ & $\begin{array}{l}\text { - increasing the mRNA expressions of pp-1, GLUT4, and PPAR- } \gamma \text {, and decreasing } \\
\text { the mRNA expressions of GSK-3 } \beta \text {, and G6PC (all involved in glucose } \\
\text { metabolism and insulin sensitivity) }\end{array}$ \\
\hline $\begin{array}{l}\text { Zhang } \\
\text { et al. }{ }^{22}\end{array}$ & $\begin{array}{l}\text { Experimental study. HFS } \\
\text { diet-induced pre-insulin } \\
\text { resistance and a low } \\
\text { dose-STZ HFS rats }\end{array}$ & Lactobacillus casei & $\begin{array}{l}\text { microbiota-based bile acid-chloride exchange mechanism: decrease in the } \\
\text { number of bile acid 7a-dehydroxylating activity possessing bacteria, bile acid } \\
\text { elimination, upregulating of chloride ion-dependent genes (CIC1-7, GlyRa1, } \\
\text { SLC26A3, SLC26A6, GABAAa1, bestrophin-3 and CFTR) and prevention of } \\
\text { chloride ion loss }\end{array}$ \\
\hline Li et al. ${ }^{23}$ & $\begin{array}{l}\text { Experimental study. } \\
\text { Type } 2 \text { diabetes in rats }\end{array}$ & $\begin{array}{l}\text { Lactobacillus plantarum } \\
\text { NCU116 }\end{array}$ & $\begin{array}{l}\text { - increasing short-chain fatty acids (SCFA) such as butyric acid in colon } \\
\text { which leads to the growth of lactobacilli and bifidobacteria and in lowering } \\
\text { intestinal pH and to increased GLP-1 secretion } \\
\text { - mRNA upregulation of glucose transporter-4 (GLUT-4) and regulation of the } \\
\text { expression of PPAR- } a \text { and PPAR- } \gamma\end{array}$ \\
\hline $\begin{array}{l}\text { Bejar } \\
\text { et al. }{ }^{24}\end{array}$ & $\begin{array}{l}\text { Experimental study. } \\
\text { Alloxan-induced } \\
\text { diabetes in rats }\end{array}$ & $\begin{array}{l}\text { Lactobacillus plantarum } \\
\text { TN627 }\end{array}$ & $\begin{array}{l}\text { - decreasing serum a-amylase activity, thus limiting the process of } \\
\text { carbohydrate hydrolysis and absorption }\end{array}$ \\
\hline
\end{tabular}


Table 1. Continues..

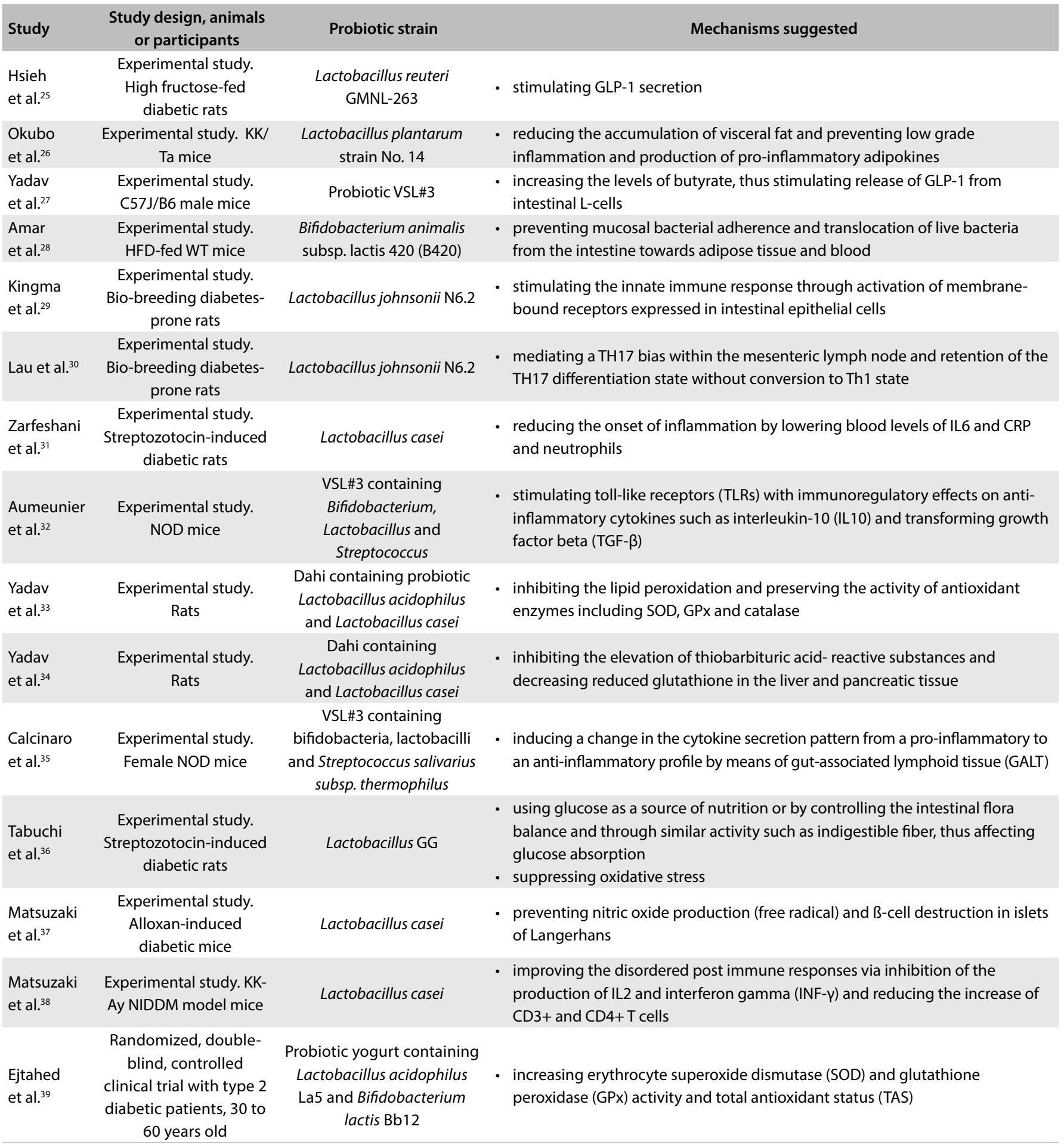

resistance in mice and suppression of endotoxemia by probiotic supplementation is considered to be a protective mechanism. ${ }^{40}$ In this regard, Balakumar et al. ${ }^{10}$ stated that probiotic interventions increased the gene expression profile of the intestinal tight junction markers and gut integrity, thereby preventing translocation of bacterial lipopolysaccharides (LPS) into the systemic circulation.
Furthermore, treatment with Lactobacillus paracasei subsp. paracasei NTU 101 may lessen the risk of type 2 diabetes mellitus through increased levels of Bifidobacterium spp. and improvement of the intestinal environment. This would preserve gut integrity and prevent translocation of bacterial lipopolysaccharides into the systemic circulation. ${ }^{18}$ 
Similarly, presence of Lactobacillus paracasei subsp. paracasei G15 and Lactobacillus casei Q14 in the gut has shown a clear correlation with reduced intestinal mucosal permeability and improved epithelial barrier function, through modification of the gut microbiota. In turn, this has been shown to lower the circulating levels of LPS and inflammatory cytokines, including interleukin (IL)-1 $\beta$ and IL-8, and possibly to alleviate the inflammatory status and islet $\beta$-cell dysfunction. ${ }^{19}$

Treatment with the probiotic Bifidobacterium animalis subsp. lactis 420 (B420) in another study ${ }^{14}$ led to protection against diabetes through prevention of mucosal bacterial adherence and translocation of live bacteria from the intestine towards adipose tissue and blood, which caused inflammation and insulin resistance.

Incretins, especially glucagon-like peptide 1 (GLP-1) secreted by intestinal L-cells, are a group of metabolic hormones that inhibit postprandial hyperglycemia by increasing the amount of insulin released from pancreatic beta cells. ${ }^{40}$ Several studies ${ }^{10,18,25}$ have shown that the beneficial effects of probiotic interventions on glucose tolerance and insulin sensitivity were related to increased levels of GLP-1.

Also, administration of Lactobacillus kefiranofaciens $M$ and Lactobacillus kefiri $K$ was found to stimulate GLP-1 production, with a concomitant decrease in the numbers of Gram-negative bacteria, which could trigger inflammation. ${ }^{19}$

The influence of human lactobacilli engineered to secrete GLP-1 on hyperglycemia has been investigated by Duanet al. ${ }^{14}$ They showed that these lactobacilli reprogram intestinal cells into glucose-responsive insulin-secreting cells and that they therefore had the ability to ameliorate hyperglycemia and diabetes.

Moreover, in some studies, the effect of probiotics on diabetes has been linked to increases in the levels of short-chain fatty acids (SCFAs), especially butyrate in the colon. ${ }^{23,27}$ SCFAs are probably key components in the growth of lactobacilli and bifidobacteria and in lowering intestinal $\mathrm{pH}$. All of these are expected to have beneficial effects on diabetes. In addition, SCFAs have been linked to increased GLP-1 secretion in both animal and human models.

Local changes to the intestinal environment and microbiota have been mentioned as another mechanism relating probiotics to diabetes prevention and treatment. Saccharomyces boulardii significantly changes the gut microbiota composition with an increased proportion of Bacteroidetes and decreased quantities of organisms in the phyla Firmicutes, Proteobacteria and Tenericutes. These phyla have been previously correlated with type 2 diabetes in mice. ${ }^{20}$
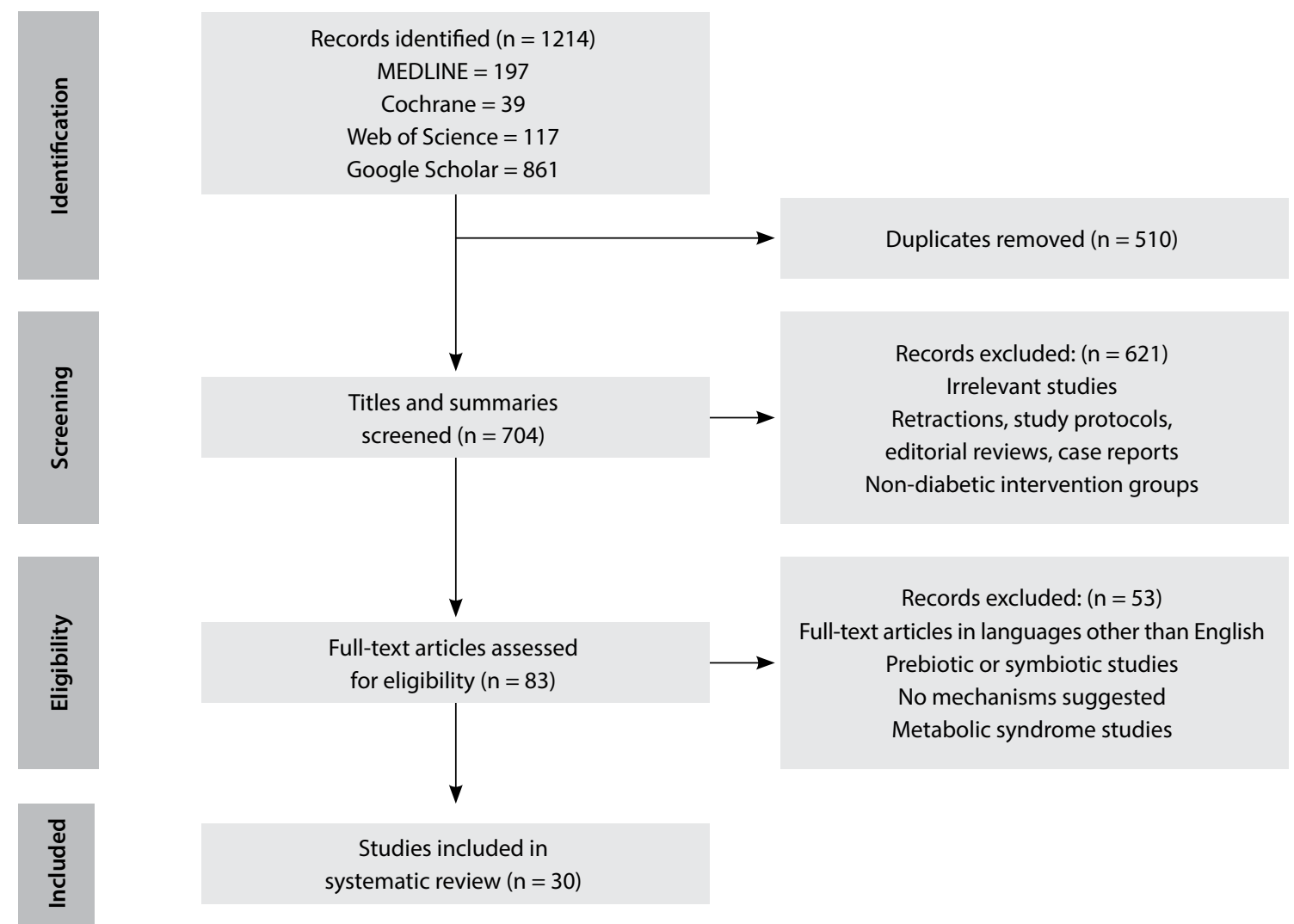

Studies included in

systematic review $(n=30)$

Figure 1. Flow chart of study selection process. 
Dolpady et al. ${ }^{13}$ also demonstrated prevention of type 1 diabetes (T1D) through enriching the local microbiota with Lactobacillaceae strains and through inducing substantial modifications in the microbiota composition, with increased levels of species of Clostridia and Rikenellaceae and decreased levels of the Bacteroidetes strain S24-7, when a Lactobacillaceae-enriched VSL\#3 probiotic was administered. In addition, these modifications generated a protolerogenic intestinal microenvironment with low expression of inflammatory IL-1 $\beta$. The VSL\#3-induced protolerogenic microenvironment promotes CD103+ dendritic cell differentiation and reduces $\mathrm{T}$ effectors/ $\mathrm{T}$ regulatory cell (Teff/Treg) ratios within the gut mucosa, mesenteric lymph nodes (MLN) and peripheral lymph nodes (PLN), which results in autoimmune diabetes prevention.

Pancreatic inflammation caused by type 1 diabetes results in leakage of a-amylase into the bloodstream, thus eliciting higher levels of serum pancreatic a-amylase, a key enzyme involved in carbohydrate digestion. Administration of L. plantarum TN627 to diabetic rats was found to significantly decrease serum $\alpha$-amylase activity, thus limiting the process of carbohydrate hydrolysis and absorption. Consequently, beneficial effects were observed on the glycemic index. ${ }^{24}$

\section{The effects of probiotics on the inflammatory and immune response pathways}

Altered production or function of circulating innate immune proteins, cellular pattern-recognition receptors and inflammatory cytokines have been linked to insulin resistance and diabetes. ${ }^{41}$

Lactobacillus kefiranofaciens $\mathrm{M}$ and lactobacillus kefiri $\mathrm{K}$ were reported to mitigate progression of type 1 diabetes through inhibiting pro-inflammatory and inflammatory cytokines and elevating the production of IL-10. IL-10 inhibits the levels of pro-inflammatory cytokines (tumor necrosis factor-alpha) and Th1 cytokines (IL-1 $\beta$, IL-2, IL-6) and prevents $\beta$ cell destruction. ${ }^{19}$

Moreover, administration of Bifidobacterium spp. increased the levels of innate immune response proteins, including I $\kappa B$ kinase

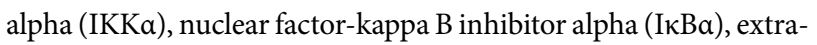
cellular-signal-regulated kinase 2 (ERK2) and protein kinase B (Akt). Akt may affect IKKa and even result in activation of IKBa, which may in turn inhibit the effects of NF- $\kappa$ Band, thus leading to reduced transcription of target genes such as those of pro-inflammatory cytokines. On the other hand, ERK, a widely-expressed protein kinase, is an intracellular signaling molecule involved in functions relating to regulation of cell proliferation, differentiation and survival. Increased ERK2 levels may induce differentiation of adipocytes into a cell type capable of inducing insulin sensitivity in diabetic mice fed with Bifidobacterium spp. ${ }^{16}$

Furthermore, Lactobacillus rhamnosus GG (LGG) treatment was shown ${ }^{17}$ to reduce infiltration and activation of macrophages, which is critical for initiation and amplification of chronic inflammation in white adipose tissues. Hence, the insulin-sensitizing effect of LGG may occur through alleviating this inflammatory pathway.

Another study ${ }^{26}$ indicated that administration of Lactobacillus plantarum No. 14 prevents development of insulin resistance, mainly through reducing accumulations of visceral fat, which prevents production of pro-inflammatory adipokines. Pro-inflammatory adipokines interfere with the insulin-signaling pathway of peripheral tissues and facilitate development of insulin resistance.

In addition, there is evidence that oral treatment with VSL\#3, a probiotic compound containing bifidobacteria, lactobacilli and Streptococcus salivarius subsp. thermophilus, induces a change in the cytokine secretion pattern from a pro-inflammatory to an antiinflammatory profile in the gut-associated lymphoid tissue (GALT), which is associated with qualitative modification of islet-specific destructive autoimmunity and, possibly, diabetes prevention. ${ }^{35}$

Consistent with the abovementioned data, protective action by Lactobacillus casei in relation to diabetes was correlated with less frequent onset of inflammation, through lowered levels of IL6, CRP and neutrophils in blood. ${ }^{31}$ Lactobacillus casei also has the potential to decrease blood glucose levels through improvement of disordered post-immune responses via inhibition of production of IL2 and interferon gamma (INF- $\gamma$ ) and reduction of the increases in $\mathrm{CD} 3+$ and CD4+ T cell counts. ${ }^{38}$

Kingma et al. ${ }^{29}$ showed that Lactobacillus johnsonii (Ljo) N6.2 stimulates the innate immune response through activation of the membrane-bound receptors expressed in intestinal epithelial cells. These receptors activate type 1 interferon (INF), which are key players in innate immunity. Therefore, a higher state of immunological activation would be achieved, thereby preventing diabetes. Moreover, this strain inhibits type 1 diabetes through mediating T-helper 17 (Th17) bias within the mesenteric lymph nodes. Retention of the Th17 differentiation state, without conversion to a Th1 state, which is critical to diabetogenesis, prevents or delays the onset of type 1 diabetes. ${ }^{30}$

Stimulation of toll-like receptors (TLRs), which have immunoregulatory effects on anti-inflammatory cytokines, can prevent the onset of autoimmune diseases. TLR-mediated effects of probiotics involve immune-regulatory cytokines such as interleukin IL-10 and transforming growth factor (TGF)- $\beta$ and some regulatory $\mathrm{T}$ cells, under the experimental conditions that result in protection from spontaneous diabetes. ${ }^{32}$

\section{The effects of probiotics on oxidative stress}

In diabetes, the free radicals that are generated cause lipid peroxidation and malondialdehyde (MDA) production. Moreover, the activity levels of reactive oxygen species scavengers are lower in patients with diabetes. Therefore, improvement of oxidative stress status may contribute towards diabetes management. ${ }^{42,43}$ 
Tabuchi et al. ${ }^{36}$ showed that Lactobacillus GG lowered the level of MDA per gram of liver weight, which conferred suppression of oxidative stress and improved glucose tolerance.

Other authors concluded that the inhibitory effect of Lactobacillus casei on the incidence of diabetes was partially dependent on prevention of nitric oxide production, given that this is a free radical that is involved in the $\beta$-cell destruction process in islets of Langerhans. ${ }^{37,44}$

On the other hand, foods containing probiotics have been shown to protect against indices relating to diabetes. In one study, probiotic yogurt consumption increased the activity levels of erythrocyte superoxide dismutase (SOD) and glutathione peroxidase (GPx), which scavenge free radicals, and improved the total antioxidant status (TAS). ${ }^{39}$

Another mechanism that was proposed to explain the action of fermented milk products containing probiotic bacteria on diabetes was through diminishing the elevation of thiobarbituric acidreactive substances and increasing glutathione levels in the liver and pancreatic tissues of diabetic rats. These findings indicated that this drink had good antioxidant properties. ${ }^{33}$

Probiotic milk has consistently been found to exert antioxidant effects through inhibiting lipid peroxidation and preserving the activity of antioxidant enzymes, including SOD, GPx and catalase (CAT) ${ }^{34}$

\section{The effects of probiotics on gene expression}

Some studies on interactions between probiotics and gene expression have suggested that type 2 diabetes in rats is ameliorated through mRNA upregulation of glucose transporter-4 (GLUT-4) through Lactobacillus plantarum NCU116 treatment. ${ }^{23}$ This has a critical role in glucose uptake. ${ }^{45}$ Moreover, NCU can regulate glucose homeostasis and insulin sensitivity in diabetic rats via regulating PPAR- $\alpha$ and PPAR- $\gamma$ gene expression. These genes play key roles in inflammation and glucose homeostasis. ${ }^{46}$

Bifidobacterium spp. also has an impact on enhanced expression of proteins involved in the insulin-signaling pathway, including IR- $\beta$, IRS- 1 and Akt. This results in improved glucose uptake and blood glucose reduction. ${ }^{16}$

Zhang et al. ${ }^{22}$ postulated that prevention of the onset of type 2 diabetes through using $L$. casei Zhang may occur via a microbiota-based bile acid-chloride exchange mechanism. Hyperglycemia relates to high levels of plasma bile acids and urine chloride ion loss. High intracellular chloride ion levels in $\beta$-cells of the pancreas are essential for the electrical activity of the $\beta$-cell membrane and for insulin release. L. casei Zhang administration was found to cause a decrease in the quantity of bacteria with bile acid $7 \alpha$-dehydroxylating activity and, therefore, bile acid elimination was enhanced. In turn, chloride ion loss was significantly prevented by $L$. casei via upregulation of chloride ion-dependent genes (ClC1-7, GlyRa1, SLC26A3, SLC26A6, GABAAa1, bestrophin-3 and CFTR).

In addition, discovery of the antidiabetic activity of Bifidobacterium lactis HY 8101 has shed new light on the mechanisms for probiotics and their importance in diabetes. ${ }^{21}$ Its antidiabetic activity occurs through increasing the mRNA expression of pp-1 (glycogen synthesis-related enzymes), GLUT4 (glucose uptakerelated genes) and PPAR- $\gamma$ (insulin sensitivity-related genes) and decreasing the mRNA expression of GSK-3 $\beta$ (glycogen synthesisrelated enzymes) and G6PC (gluconeogenesis-related enzymes), which are all involved in glucose metabolism and insulin sensitivity.

Another investigation $^{15}$ also provided evidence that a multispecies mixture of probiotics containing Lactobacillus and Bifidobacterium reduced expression of the gene encoding CCL2. The latter is an important chemokine for macrophage infiltration of adipose tissue and contributes towards insulin resistance. ${ }^{47}$

Finally, endoplasmic reticulum (ER) stress has been mentioned as one of the main causes of development of inflammation and insulin resistance. ER stress appears to act directly as a negative modulator of the insulin signaling pathway, but also indirectly by promoting lipid accumulation. ${ }^{48}$ Two studies ${ }^{10,17}$ showed that probiotic interventions alleviated lipotoxicity and ER stress gene expression in skeletal muscle, which resulted in improvement of glucose tolerance.

\section{DISCUSSION}

One significant question regarding clinical use of probiotics is the mechanism underlying the wide range of actions. However, the increasing number of studies that are being conducted with the aim of establishing probiotic mechanisms relating to diabetes conditions indicate that there is a promising future for probiotics in treating this disease. To the best of our knowledge, this is the first review on the mechanisms of probiotic function relating to diabetes. It is hoped that gaining a mechanistic understanding of probiotic action will provide the rationale to support development of new hypothesis-driven studies to define the clinical efficacy of preventive, adjunctive or alternative treatments for diabetes. Also, such efforts could suitably help in selecting strains for specific investigation and applications under these conditions and may uncover novel probiotic functions.

The mechanisms suggested have mostly involved intraluminal and direct effects on intestinal mucosa and microbiota (13 studies). Suppression of endotoxemia, stimulation of secretion of short chain fatty acids (SCFAs) and incretines, and local changes to the gut environment and microbiota were major effects detailed in the present review. In addition, anti-inflammatory and immunomodulatory effects were reported in 10 studies. Prevention of free radical production, increased activity of antioxidant enzymes and inhibition of peroxidation were reported as the main antioxidant 
effects of probiotics in relation to diabetes (five studies). Finally, six studies suggested that probiotics might have effects through altering the expression of genes involved in ER stress and glucose homeostasis and insulin resistance.

The strengths of this review include its use of an outcome classification for different possible mechanisms of probiotics in relation to diabetes. However, several limitations need to be taken into account in interpreting our findings. It should be mentioned that, except for one study, all of these mechanisms have been verified in animal studies. Moreover, it seems that such effects depend on the type of bacteria, dose and duration of consumption, manner and frequency of administration, environmental factors and complex interactions between probiotics, cells and metabolic pathways that are rarely mediated by a single mechanism. ${ }^{49}$

In addition, it is important to take into consideration the risk of bias across different studies, such as publication, performance and reporting bias, along with potential conflicts of interest. Such factors might limit the ability to draw robust conclusions from these studies. Given that we only had limited access to some databases such as Embase, and that studies not reported in English were excluded, it is possible that more rigorous reporting of study results would improve the quality of the evidence in further studies.

Nonetheless, elucidation of the mechanisms linking the microbiome to diabetes can provide a rational basis for dietary consumption of probiotic microorganisms in relation to diabetes. In addition, evaluation of the mechanism of action for probiotics both in healthy subjects and in diabetic patients, so as to address the influence of these microorganisms on gene expression for different pathways, is needed in order to better understand the role that probiotics might have in prevention and treatment of diabetes.

\section{CONCLUSIONS}

In conclusion, there is some evidence suggesting various potential mechanisms of action for probiotics in relation to diabetes prevention and treatment. Further studies are needed to confirm the underlying pathways involved in the beneficial effects from each strain, along with assessment of other confounding factors.

\section{REFERENCES}

1. Hemarajata P, Versalovic J. Effects of probiotics on gut microbiota: mechanisms of intestinal immunomodulation and neuromodulation. Therap Adv Gastroenterol. 2013;6(1):39-51.

2. Ozdemir O. Various effects of different probiotic strains in allergic disorders: an update from laboratory and clinical data. Clin Exp Immunol. 2010;160(3):295-304.

3. Idzior Waluś B, Waluś-Miarka M. Is now the time for probiotics in diabetes management? Pol Arch Med Wewn. 2015;125(11):797-8.
4. Tonucci LB, Olbrich Dos Santos KM, Licursi de Oliveira L, Rocha Ribeiro SM, Duarte Martino HS. Clinical application of probiotics in type 2 diabetes mellitus: A randomized, double-blind, placebo-controlled study. Clin Nutr. 2015;pii: S0261-5614(15)00331-3.

5. Kasińska MA, Drzewoski J. Effectiveness of probiotics in type 2 diabetes: a meta-analysis. Pol Arch Med Wewn. 2015;125(11):803-13.

6. Tremaroli V, Bäckhed F. Functional interactions between the gut microbiota and host metabolism. Nature. 2012;489(7415):242-9.

7. Kim JJ, Sears DD. TLR4 and Insulin Resistance. Gastroenterol Res Pract. 2010;2010. pii: 212563.

8. Moher D, Liberati A, Tetzlaff J, Altman DG; PRISMA Group. Preferred reporting items for systematic reviews and meta-analyses: the PRISMA statement. Ann Intern Med. 2009;151(4):264-9, W64.

9. Everard A, Cani PD. Diabetes, obesity and gut microbiota. Best Pract Res Clin Gastroenterol. 2013;27(1):73-83.

10. Balakumar M, Prabhu D, Sathishkumar C, et al. Improvement in glucose tolerance and insulin sensitivity by probiotic strains of Indian gut origin in high-fat diet-fed C57BL/6J mice. Eur J Nutr. 2016. [Epub ahead of print].

11. Hung S-C, Tseng W-T, Pan T-M. Lactobacillus paracasei subsp. paracasei NTU 101 ameliorates impaired glucose tolerance induced by a highfat, high-fructose diet in Sprague-Dawley rats. Journal of Functional Foods. 2016;24:472-81. Available from: http://www.sciencedirect.com/ science/article/pii/S1756464616301086. Accessed in 2017 (Feb 2)

12. Tian P, Li B, He C, et al. Antidiabetic (type 2) effects of Lactobacillus G15 and Q14 in rats through regulation of intestinal permeability and microbiota. Food Funct. 2016;7(9):3789-97.

13. Dolpady J, Sorini C, Di Pietro C, et al. Oral Probiotic VSL\#3 Prevents Autoimmune Diabetes by Modulating Microbiota and Promoting Indoleamine 2,3-Dioxygenase-Enriched Tolerogenic Intestinal Environment. J Diabetes Res. 2016; 2016:7569431.

14. Duan FF, Liu JH, March JC. Engineered commensal bacteria reprogram intestinal cells into glucose-responsive insulin-secreting cells for the treatment of diabetes. Diabetes. 2015;64(5):1794-803.

15. Holowacz S, Guigné C, Chêne G, et al. A multispecies Lactobacillus- and Bifidobacterium-containing probiotic mixture attenuates body weight gain and insulin resistance after a short-term challenge with a high-fat diet in C57/BL6J mice. PharmaNutrition.2015; 3(3): 1017. Available from: http://www.sciencedirect.com/science/article/pii/S2213434415000158. Accessed in 2017 (Feb 2).

16. Le TK, Hosaka T, Nguyen TT, et al. Bifidobacterium species lower serum glucose, increase expressions of insulin signaling proteins, and improve adipokine profile in diabetic mice. Biomed Res. 2015;36(1):63-70.

17. Park KY, Kim B, Hyun CK. Lactobacillus rhamnosus GG improves glucose tolerance through alleviating ER stress and suppressing macrophage activation in db/db mice. J Clin Biochem Nutr. 2015;56(3):240-6.

18. Stenman LK, Waget A, Garret C, et al. Probiotic B420 and prebiotic polydextrose improve efficacy of antidiabetic drugs in mice. Diabetol Metab Syndr. 2015; 7:75. 
19. Wei S-H, Chen Y-P, Chen M-J. Selecting probiotics with the abilities of enhancing GLP-1 to mitigate the progression of type 1 diabetes in vitro and in vivo. Journal of Functional Foods. 2015;18 (Part A):473-86. Available from: http://www.sciencedirect.com/science/article/pii/ S1756464615004004. Accessed in 2017 (Feb 2).

20. Everard A, Matamoros S, Geurts L, Delzenne NM, Cani PD. Saccharomyces boulardii administration changes gut microbiota and reduces hepatic steatosis, low-grade inflammation, and fat mass in obese and type 2 diabetic db/db mice. MBio. 2014;5(3):e01011-14.

21. Kim SH, Huh CS, Choi ID, et al. The anti-diabetic activity of Bifidobacterium lactis HY8101 in vitro and in vivo. J Appl Microbiol. 2014;117(3):834-45.

22. Zhang Y, Guo X, Guo J, et al. Lactobacillus casei reduces susceptibility to type 2 diabetes via microbiota-mediated body chloride ion influx. Sci Rep. 2014; 4:5654.

23. Li C, Ding Q, Nie SP, et al. Carrot juice fermented with Lactobacillus plantarum NCU116 ameliorates type 2 diabetes in rats. J Agric Food Chem. 2014;62(49):11884-91.

24. BejarW, Hamden K, Ben Salah R, Chouayekh H. Lactobacillus plantarum TN627 significantly reduces complications of alloxan-induced diabetes in rats. Anaerobe. 2013; 24:4-11.

25. Hsieh FC, Lee CL, Chai CY, et al. Oral administration of Lactobacillus reuteri GMNL-263 improves insulin resistance and ameliorates hepatic steatosis in high fructose-fed rats. Nutr Metab (Lond). 2013;10(1):35.

26. Okubo T, Takemura N, Yoshida A, Sonoyama K. KK/Ta Mice Administered Lactobacillus plantarum Strain No. 14 Have Lower Adiposity and Higher Insulin Sensitivity. Biosci Microbiota Food Health. 2013;32(3):93-100.

27. Yadav H, Lee JH, Lloyd J, Walter P, Rane SG. Beneficial metabolic effects of a probiotic via butyrate-induced GLP-1 hormone secretion. J Biol Chem. 2013;288(35):25088-97.

28. Amar J, Chabo C, Waget A, et al. Intestinal mucosal adherence and translocation of commensal bacteria at the early onset of type 2 diabetes: molecular mechanisms and probiotic treatment. EMBO Mol Med. 2011;3(9):559-72.

29. Kingma SD, Li N, Sun F, et al. Lactobacillus johnsonii N6.2 stimulates the innate immune response through Toll-like receptor 9 in Caco-2 cells and increases intestinal crypt Paneth cell number in biobreeding diabetes-prone rats. J Nutr. 2011;141(6):1023-8.

30. Lau K, Benitez P, Ardissone A, et al. Inhibition of type 1 diabetes correlated to a Lactobacillus johnsonii N6.2-mediated Th17 bias. J Immunol. 2011;186(6):3538-46

31. Zarfeshani A, Khaza'ai H, Mohd Ali R, et al. Effect of Lactobacillus casei on the Production of Pro-Inflammatory Markers in Streptozotocin-Induced Diabetic Rats. Probiotics Antimicrob Proteins. 2011;3(3-4):168-74.

32. Aumeunier A, Grela F, Ramadan A, et al. Systemic Toll-like receptor stimulation suppresses experimental allergic asthma and autoimmune diabetes in NOD mice. PloS One. 2010;5(7): e11484.
33. Yadav H, Jain S, Sinha PR. Antidiabetic effect of probiotic dahi containing Lactobacillus acidophilus and Lactobacillus casei in high fructose fed rats. Nutrition. 2007;23(1):62-8.

34. Yadav H, Jain S, Sinha PR. Oral administration of dahi containing probiotic Lactobacillus acidophilus and Lactobacillus casei delayed the progression of streptozotocin-induced diabetes in rats. J Dairy Res. 2008;75(2):189-95.

35. Calcinaro F, Dionisi S, Marinaro M, et al. Oral probiotic administration induces interleukin-10 production and prevents spontaneous autoimmune diabetes in the non-obese diabetic mouse. Diabetologia. 2005:48(8):1565-75.

36. Tabuchi M, Ozaki M, Tamura A, et al. Antidiabetic effect of Lactobacillus GG in streptozotocin-induced diabetic rats. Biosci Biotechnol Biochem. 2003;67(6):1421-4.

37. Matsuzaki T, Nagata $Y$, Kado $S$, et al. Effect of oral administration of Lactobacillus casei on alloxan-induced diabetes in mice. APMIS. 1997;105(8):637-42.

38. Matsuzaki T, Yamazaki R, Hashimoto S, Yokokura T. Antidiabetic effects of an oral administration of Lactobacillus casei in a non-insulindependent diabetes mellitus (NIDDM) model using KK-Ay mice. Endocr J. 1997;44(3):357-65.

39. Ejtahed HS, Mohtadi-Nia J, Homayouni-Rad A, et al. Probiotic yogurt improves antioxidant status in type 2 diabetic patients. Nutrition. 2012;28(5):539-43.

40. Holst JJ. The physiology of glucagon-like peptide 1. Physiol Rev. 2007;87(4):1409-39.

41. Fernández-Real JM, Pickup JC. Innate immunity, insulin resistance and type 2 diabetes. Diabetologia. 2012; 55(2):273-8.

42. Maritim AC, Sanders RA, Watkins JB 3rd. Diabetes, oxidative stress, and antioxidants: a review. J Biochem Mol Toxicol. 2003;17(1):24-38.

43. Rahbani-Nobar M, Rahimi-Pour A, Rahbani-Nobar M, Adi-Beig F, Mirhashemi SM. Total antioxidant capacity, superoxide dismutase and glutathione peroxidase in diabetic patients. Medical Journal of Islamic Academy Sciences. 1999;12(4):109-14. Available from: http:// www.journalagent.com/ias/pdfs/IAS_12_4_109_114.pdf. Accessed in 2017 (Feb 2).

44. Kasuga A, Nakaki T, Takei I, et al. Nitric oxide is important for mouse beta-cell line killing by peritoneal exudate cells obtained from cyclophosphamide treated non-obese diabetic mice. Endrocr J. 1995;42(2):259-63.

45. Kim SW, Park KY, Kim B, Kim E, Hyun CK. Lactobacillus rhamnosus GG improves insulin sensitivity and reduces adiposity in high-fat diet-fed mice through enhancement of adiponectin production. Biochem Biophys Res Commun. 2013;431(2):258-63.

46. Soares FL, de Oliveira Matoso R, Teixeira LG, et al. Gluten-free diet reduces adiposity, inflammation and insulin resistance associated with the induction of PPAR-alpha and PPAR-gamma expression. J Nutr Biochem. 2013;24(6):1105-11. 
47. Kanda H, Tateya S, Tamori Y, et al. MCP-1 contributes to macrophage infiltration into adipose tissue, insulin resistance, and hepatic steatosis in obesity. J Clin Invest. 2006;116(6):1494-505.

48. Flamment M, Hajduch E, Ferré P, Foufelle F. New insights into ER stressinduced insulin resistance. Trends Endocrinol Metab. 2012;23(8):381-90.

49. Boyle RJ, Robins-Browne RM, Tang ML. Probiotic use in clinical practice: what are the risks? Am J Clin Nutr. 2006;83(6):1256-64; quiz 1446-7.

Acknowledgements: This study was supported by the Isfahan University of Medical Sciences, Isfahan, Iran

Authors' contributions: NR, SGH and SS searched databases and

selected articles. MM, NR, SGH, SS and RGH wrote the manuscript. All authors read and approved the content of the manuscript

Sources of funding: None

Conflict of interest: None

\section{Address for correspondence:}

Reza Ghiasvand

Department of Community Nutrition

School of Nutrition and Food Science

Isfahan University of Medical Sciences

Isfahan - Iran

Tel. 0098 313792-3153

Fax. 0098 313668-2509

E-mail: ghiasvand@hlth.mui.ac.ir 